\title{
INTERFERENCJE LEKSYKALNE W WYPOWIEDZIACH PISEMNYCH SLOWIAN ZE WSCHODU (NA PODSTAWIE PISEMNYCH PRAC CERTYFIKATOWYCH Z ROKU 2019, POZIOM B1)
}

\begin{abstract}
Słowa kluczowe: interferencja, błędy leksykalne, negatywny transfer językowy, egzamin certyfikatowy, poziom B1

Streszczenie. W artykule poddano analizie interferencyjne błędy leksykalne popełniane przez Słowian ze Wschodu. Podjęto również próbę ich klasyfikacji oraz wskazanie źródeł powstawania. Materiał źródłowy stanowią wypowiedzi pisemne, zaczerpnięte z testów certyfikatowych (poziom B1). Błędy podzielono na kilka grup z uwagi na ich wpływ na skuteczność komunikacyjną osób pochodzenia wschodniosłowiańskiego uczących się JPJO. Prezentowany materiał może służyć pomocą do opracowywania zadań zapobiegających interferencji leksykalnej.
\end{abstract}

Interferencji językowej w glottodydaktycznej literaturze polonistycznej poświęcono już wiele miejsca (zob. np.: Dunin-Dudkowska, Maliszewski 2018, Czernysz 2005, Górecki, Stawska 1993, Izdebska-Długosz 2016, Kowalewski 2015, Krawczuk 2006, Przechodzka 1993 i in.), ponieważ błędy językowe powstałe w wyniku jej działania wpływają na skuteczność komunikacyjną uczących się polszczyzny. Interferencja zewnątrzjęzykowa to „wszelkie odchylenia od reguł danego systemu języka lub normy językowej, które [...] mówiący językiem obcym popełnia, przyporządkowując określone reguły [...] do reguł innego systemu językowego" (Szulc 1984, s. 94). W przypadku cudzoziemców jest to

"grazyna.przechodzka@mail.umcs.pl, Centrum Języka i Kultury Polskiej UMCS, ul. Weteranów 18, 20-038 Lublin.

***wiktorija.hudy@mail.umcs.pl, Centrum Języka i Kultury Polskiej UMCS, ul. Weteranów 18, 20-038 Lublin. 
negatywny wpływ języka ojczystego na przyswajany język polski. Błędy interferencyjne mogą więc zakłócać, utrudniać bądź wręcz uniemożliwiać komunikację. Interferencja zewnątrzjęzykowa dotyczy wszystkich elementów kompetencji lingwistycznej, która - jako element składowy językowej kompetencji komunikacyjnej - zakłada opanowanie podsystemów języka: gramatyki, leksyki, fonetyki i ortografii. Na tej podstawie U. Żydek-Bednarczuk wyodrębnia błędy interferencyjne, dzieląc je na fonetyczne, morfologiczne, leksykalne i słowotwórcze oraz składniowe (zob.: Żydek-Bednarczuk 1993, s. 69-82).

Celem niniejszego artykułu jest analiza błędów leksykalnych, próba ich klasyfikacji oraz wskazanie źródeł powstawania. Przedmiotem zainteresowania glottodydaktyków polonistycznych jest głównie interferencja w zakresie kompetencji gramatycznej, natomiast niewiele miejsca zajmują w publikacjach interferencyjne błędy słownikowe (zob.: Czapla 2020). Materiał egzemplifikacyjny analizy stanowią wypowiedzi pisemne osób pochodzenia wschodniosłowiańskiego zaczerpnięte, z testów certyfikatowych z egzaminu przeprowadzonego w roku 2019 w Centrum Języka i Kultury Polskiej dla Polonii i Cudzoziemców UMCS. Analizie poddano 210 prac z poziomu B1 cieszącego się wśród cudzoziemców największą popularnością ${ }^{1}$. Na użytek niniejszego artykułu przyjęto definicję kompetencji leksykalnej zawartą w Europejskim systemie opisu ksztatcenia językowego, zgodnie z którą: „kompetencja leksykalna to znajomość i umiejętność użycia stownictwa danego języka. Składaja się na nia elementy leksykalne i gramatyczne" (ESOKJ 2003, s. 101). Do elementów leksykalnych należą: stałe wyrażenia (utarte formuły, wyrażenia idiomatyczne, zwroty szablonowe, stałe związki wyrazowe i kolokacje), a także pojedyncze słowa (ESOKJ 2003, s. 101). Jakość kompetencji leksykalnej ma pierwszorzędne znaczenie w nauce języka, ponieważ jej główny cel to takie jego opanowanie, aby móc skutecznie porozumiewać się z rodzimymi użytkownikami języka. Z tego względu ,[...] słownictwo odgrywa w nauczaniu bardzo dużą rolę. Dzieje się tak dlatego, że umiejętność przekazu informacji jest najsilniej uzależniona od poziomu opanowania słownictwa. To właśnie braki leksykalne najsilniej uszkadzają, a niekiedy wręcz blokują przekaz. Znacznie mniejszą rolę odgrywa fakt, czy wypowiedź jest poprawna gramatycznie, czy też nie. Blokada komunikacji to najczęściej skutek nieznajomości potrzebnego słownictwa" (Komorowska 2001, s. 115).

Braki słownikowe są szczególnie zauważalne w wypowiedziach pisemnych, gdyż zdający nie mogą się w nich wspomagać pozawerbalnymi środkami komunikacji (gesty, mimika), pomocnymi w przekazach ustnych. $Z$ tego, m.in., powodu osiągają znacznie lepsze wyniki z modułu Mówienie, zaś zdecydowanie

${ }^{1}$ W 2019 r. państwowy egzamin z języka polskiego jako obcego zdawało ponad 6500 osób, z czego 80\% zdających (ok. 5230) wybrało poziom B1, będący najniższym poziomem biegłości językowej wymaganym przez ustawodawcę w celu ubiegania się przez cudzoziemców o polskie obywatelstwo (zob.: Dz.U. 2012 poz. 161). 
gorsze - z modułu Pisanie, z którego negatywna ocena przesądza często o ostatecznym wyniku egzaminu.

Podstawowym źródłem interferencyjnych błędów leksykalnych popełnianych przez zdających jest przede wszystkim wspólne, słowiańskie pochodzenie języka polskiego i języków wschodniosłowiańskich. W swoich wypowiedziach dokonują więc często negatywnego transferu z języków ojczystych i to nie tylko w zakresie gramatyki, ale również leksyki.

Prezentowane w artykule błędy leksykalne pogrupowano w oparciu o klasyfikację A. Dąbrowskiej i M. Pasieki (Dąbrowska, Pasieka 2008, s. 94-98), koncentrując się na błędach użycia, do których w zakresie leksyki autorki zaliczają:

- „fałszywych przyjaciół”;

- $\quad$ kalki;

- zapożyczenia;

- błędy w zakresie frazeologii.

Źródłem powstawania pierwszej grupy błędów jest homonimia międzyjęzykowa. Dotyczy ona słów podobnych fonetycznie, ale różniących się znaczeniowo, przysparzając uczącym się najwięcej trudności w poprawnym ich użyciu. Piszący sięgają po nie w przekonaniu, że skoro brzmią podobnie (lub tak samo), to mają również podobne znaczenie, co w efekcie powoduje nieporozumienia komunikacyjne. W tabeli 1 zaprezentowano przykłady takich błędów.

Tabela 1. Homonimy

\begin{tabular}{|c|c|c|c|}
\hline Lp. & Przykład & $\begin{array}{c}\text { Powinno być } \\
\text { (znaczenie polskie) }\end{array}$ & Znaczenie rosyjskie/ukraińskie \\
\hline 1 & pismo (Piszę do Pani pismo) & w zn.: list & ros. письмо, ukr. лист \\
\hline 2 & lekcja & w zn.: wykład & ros. лекция, ukr. лекція \\
\hline 3 & pozdrawiam ze światem & w zn.: życzę & ros.поздравляю, ukr. вітаю \\
\hline 4 & $\begin{array}{l}\text { składa się z pieńciu serij } \\
\text { (o serialu) }\end{array}$ & $\begin{array}{l}\text { w zn.: odcinków } \\
\text { (odcinek) }\end{array}$ & ros. серия, ukr. серія \\
\hline 5 & nazwa serialu & w zn.: tytuł & ros. название, ukr. назва \\
\hline 6 & dziękuję za rozumienie & w zn.: wyrozumiałość & ros. понимание, ukr. розуміння \\
\hline 7 & gumki do żucia & w zn.: gumy & $\begin{array}{l}\text { ros. жевательные резинки, } \\
\text { ukr. жувальні гумки }\end{array}$ \\
\hline 8 & to jest bardzo lekko & w zn.: łatwo & ros. легко, ukr. легко \\
\hline 9 & $\begin{array}{l}\text { kilka razy złamałam } \\
\text { komputer }\end{array}$ & w zn.: zepsułam & ros. поламать, ukr. поламати \\
\hline 10 & na ostatnim kursie & w zn.: roku & ros. курс, ukr. курс \\
\hline 11 & fotel ma ładny wizerunek & w zn.: kształt/wzór & ros. узор, ukr. візерунок \\
\hline 12 & $\begin{array}{l}\text { konkurs przechodził } \\
\text { w Kijowie }\end{array}$ & w zn.: odbywał się & ros. проходить, ukr. проходити \\
\hline
\end{tabular}


Tabela 1 (cd.)

\begin{tabular}{|c|c|c|c|}
\hline Lp. & Przykład & $\begin{array}{c}\text { Powinno być } \\
\text { (znaczenie polskie) }\end{array}$ & Znaczenie rosyjskie/ukraińskie \\
\hline 13 & $\begin{array}{l}\text { do konkursu gotował się } \\
\text { bardzo długo }\end{array}$ & $\begin{array}{l}\text { w zn.: przygotowywał } \\
\text { się }\end{array}$ & ros. готовиться, ukr. готуватися \\
\hline 14 & stół i policzki & w zn.: półki & ros. полки, ukr. полички \\
\hline 15 & umowy konkursu & w zn.: warunki & ros. условия, ukr. умови \\
\hline 16 & szczęśliwego braku & w zn.: małżeństwa & ros. брак, ukr. шлюб \\
\hline 17 & zaginął jutro & w zn.: rano & ros. утром, ukr. зранку \\
\hline 18 & otrzyma wynagrodzenie & w zn.: nagrodę & $\begin{array}{l}\text { ros. вознагрождение, } \\
\text { ukr. винагорода }\end{array}$ \\
\hline 19 & dobraliśmy do Albanii & w zn.: dotarliśmy & ros. добраться, ukr. добратися \\
\hline 20 & wyzwali pogotowie & w zn.: wezwali & ros. вызвать, ukr. викликати \\
\hline 21 & nie mogę się w tym rozebrać & w zn.: zrozumieć & ros. разобраться, ukr. розібратися \\
\hline 22 & kompania lotnicza & w zn.: firma & ros. компания, ukr. компанія \\
\hline 23 & z powagą & w zn.: z poważaniem & ros. с уважением, ukr. з повагою \\
\hline 24 & kulinarne recepty & w zn.: przepisy & ros. рецепты, ukr. рецепти \\
\hline 25 & dużo mało czasu & w zn.: bardzo & ros. очень, ukr. дуже \\
\hline 26 & muszą mieć metę & w zn.: cel & ros. цель, ukr. мета \\
\hline 27 & rozpowiadać dzieciom & w zn.: opowiadać & $\begin{array}{l}\text { ros. рассказывать, ukr. } \\
\text { розповідати }\end{array}$ \\
\hline 28 & znasz, że mam książkę & w zn.: wiesz & ros. знать, ukr. знати \\
\hline 29 & plusem jest wysoka opłata & w zn.: pensja & ros. зарплата, ukr. зарплата \\
\hline 30 & muszę podgotować esej & w zn.: przygotować & $\begin{array}{l}\text { ros. подготовить, } \\
\text { ukr. підготувати }\end{array}$ \\
\hline 31 & stół ma rozmiar & w zn.: wymiar & ros. размер, ukr. розмір \\
\hline 32 & mogę dostawić meble & w zn.: dostarczyć & ros. доставить, ukr. доставити \\
\hline 33 & $\begin{array}{l}\text { włożył wse swóji nawyki, } \\
\text { żeby zrobić stół }\end{array}$ & w zn.: umiejętności & ros. навыки, ukr. навички \\
\hline 34 & $\begin{array}{l}\text { plac zabaw, na którym można } \\
\text { grać }\end{array}$ & w zn.: bawić się & ros. играть, ukr. грати \\
\hline 35 & znajduje się krzesło & w zn.: fotel & ros. кресло, ukr. крісло \\
\hline 36 & znajduje się piękny komin & w zn.: kominek & ros. камин, ukr. камін \\
\hline 37 & popadało słońce & w zn.: wpadało & ros. попадать, ukr. потрапляти \\
\hline 38 & $\begin{array}{l}\text { herbata } \mathrm{z} \text { liści miejscowej } \\
\text { trawy }\end{array}$ & w zn.: ziół & ros. травы, ukr. трави \\
\hline 39 & $\begin{array}{l}\text { zdążyliśmy zaskoczyć do } \\
\text { sklepu }\end{array}$ & w zn.: wstąpić & ros. заскочить, ukr. заскочити \\
\hline 40 & mieszkańcy mojego budynku & w zn.: domu & ros. дом, ukr. будинок \\
\hline 41 & $\begin{array}{l}\text { naprzód serdecznie } \\
\text { przepraszam }\end{array}$ & w zn.: z góry & ros. заранее, ukr. заздалегідь \\
\hline
\end{tabular}

Źródło: opracowanie własne 
Błędy leksykalne zaprezentowane w tabeli 1 występują głównie w zakresie użycia rzeczowników i czasowników, powodując czasami poważne zakłócenia w komunikacji językowej, np.: muszą mieć metę w potocznej polszczyźnie oznacza mieć, gdzie się zatrzymać. Tymczasem piszącemu chodziło tu o polskie słowo cel. Niezrozumienie intencji zdającego powoduje również zdanie: ogłoszono umowy konkursu. Zgodnie z definicją ,umowa to pisemne lub ustne porozumienie stron, mające na celu ustalenie wzajemnych praw i obowiązków" (SJP 1981, s. 600). Polski odbiorca nie zrozumie więc, co piszący miał na myśli. Źródłem błędu jest w tym przypadku język ukraiński, w którym umowa oznacza warunek.

Błędy leksykalne nie tylko zaburzają komunikację, niektóre z nich mogą ośmieszać nadawcę w kontaktach z rodzimymi użytkownikami języka. Wyrażenia typu: muszę podgotować esej, życze szczęśliwego braku, w zestawie jest stót i policzki (ukr. policzki $=$ pol. pótki) powodują niezrozumienie (zestawienie wyrazów stót i policz$k i$ intencji piszącego, mogą również wywołać zakłopotanie odbiorcy komunikatu. Jednak zdania typu: Bytiśmy tak zmęczone, że nie mogtiśmy się ruchać, Nie mogę się w tym rozebrać mogą nie tylko ośmieszyć piszącego, ale wręcz go skompromitować.

Charakter niektórych błędów przedstawionych w tabeli wynika $\mathrm{z}$ negatywnego transferu jednocześnie $\mathrm{z}$ dwóch języków: rosyjskiego i ukraińskiego. Występują one często w tej samej pracy, co może świadczyć o tym, że osoby piszące są dwujęzyczne, zaś polski jest dla nich językiem trzecim. Sugeruje to, np., zdanie pozdrawiam ze światem, w którym pozdrawiam pochodzi z języka rosyjskiego поздравляю, zaś światem z ukraińskiego зі святом (pol. święto).

Kolejną grupę błędów stanowią kalki leksykalne, które w wypowiedziach zdających są efektem thumaczenia przez piszących rodzimych elementów językowych na język polski. Przykłady tego typu błędów przedstawiono w tabeli 2.

Tabela 2. Kalki leksykalne

\begin{tabular}{|c|l|l|l|}
\hline Lp. & \multicolumn{1}{|c|}{ Przyklad } & \multicolumn{1}{|c|}{$\begin{array}{c}\text { Powinno być } \\
\text { (znaczenie polskie) }\end{array}$} & \multicolumn{1}{|c|}{$\begin{array}{c}\text { Znaczenie rosyjskie } \\
\text { /ukraińskie }\end{array}$} \\
\hline 1 & pozdrawiam ze światem & w zn.: świętem & ros. праздник, ukr. свято \\
\hline 2 & podróż na dwóch & w zn.: we dwoje & ros. на двоих, ukr. на двох \\
\hline 3 & przyjmować udział & w zn.: brać udział & $\begin{array}{l}\text { ros. принимать участие, } \\
\text { ukr. брати участь }\end{array}$ \\
\hline 4 & stoi straszny upał & w zn.: jest & ros. стоит, ukr. стоїть \\
\hline 5 & mi nie wystarcza ciebie & w zn.: brakuje & $\begin{array}{l}\text { ros. не хватает, } \\
\text { ukr. не вистачає }\end{array}$ \\
\hline 6 & spotkała nas fajna pogoda & w zn.: mielismy & ros. встретить, иkr. зустріти \\
\hline 7 & trafiłem pod silny deszcz & pot. złapał mnie & ros. попасть, ukr. потрапити \\
\hline 8 & bardzo szkoduje & w zn.: żałuje & ros. жалеть, ukr. шкодувати \\
\hline 9 & ta sprawa tak mi zaciągnęła & w zn.: wciągnęła & ros. втянуть, ukr. затягнути \\
\hline 10 & stawimy małe spektakle & w zn.: wystawiamy & ros. ставить, ukr. ставити \\
\hline
\end{tabular}


Tabela 2 (cd.)

\begin{tabular}{|c|c|c|c|}
\hline Lp. & Przykład & $\begin{array}{c}\text { Powinno być } \\
\text { (znaczenie polskie) }\end{array}$ & $\begin{array}{l}\text { Znaczenie rosyjskie } \\
\text { /ukraińskie }\end{array}$ \\
\hline 11 & jej poznania kulinarne & w zn.: wiedza & ros. знания, ukr. знання \\
\hline 12 & pozdrowili mi z wygraniem & w zn.: pogratulowali & ros. поздравить, ukr. привітати \\
\hline 13 & jak sprawy & w zn.: co słychać & ros. как дела, ukr. як справи \\
\hline 14 & $\begin{array}{l}\text { proszę postawić się } \\
\text { z rozumieniem }\end{array}$ & $\begin{array}{l}\text { w zn.: proszę } \\
\text { o wyrozumiałość }\end{array}$ & $\begin{array}{l}\text { ros. прошу отнестись } \\
\text { с пониманием, ukr. прошу } \\
\text { поставитися з розумінням }\end{array}$ \\
\hline 15 & czas od czasu & w zn.: od czasu do czasu & $\begin{array}{l}\text { ros. время от времени, } \\
\text { ukr. час від часу }\end{array}$ \\
\hline 16 & w setki raz & w zn.: sto razy & $\begin{array}{l}\text { ros. в сотни раз, } \\
\text { ukr. в сотні раз }\end{array}$ \\
\hline 17 & jednego razu & w zn.: pewnego razu & ros. однажды, ukr. одного разу \\
\hline 18 & liczyłem, że są dla kobiet & w zn.: uważałam & ros. считать, ukr. вважати \\
\hline 19 & więcej lubiłem & w zn.: bardziej & ros. больше, ukr. більше \\
\hline
\end{tabular}

Źródło: opracowanie własne

Część błędów zaprezentowanych w tabeli 2 nie uniemożliwia zrozumienia intencji piszącego, jednak wpływa na jakość jego polszczyzny. Stanowią one dosłowne tłumaczenia z języka ukraińskiego bądź rosyjskiego. Czytając, np. pozdrowili mi z wygraniem, trafitem pod silny deszcz, mi nie wystarcza ciebie, stoi straszny upat odbiorca zrozumie, co nadawca miał na myśli. Inne natomiast, np.: proszę postawić się z rozumieniem czy podróż na dwóch mogą już powodować poważne zakłócenia komunikacyjne.

Kolejna grupa błędów leksykalnych to zapożyczenia z języka ojczystego, w przypadku analizowanych prac $-\mathrm{z}$ języka rosyjskiego lub ukraińskiego. Źródłem ich powstawania jest brak znajomości polskiego słownictwa potrzebnego w danej sytuacji komunikacyjnej. Zdający sięgają więc do ojczystego zasobu leksykalnego, pisząc rodzime słowa polskimi literami, wychodząc zapewne z założenia, że w danym kontekście będą one zrozumiałe. W tabeli 3 zaprezentowano przykłady takich zapożyczeń.

Tabela 3. Zapożyczenia interferencyjne

\begin{tabular}{|c|l|l|l|}
\hline Lp. & \multicolumn{1}{|c|}{ Przykład } & \multicolumn{1}{|c|}{$\begin{array}{c}\text { Powinno być } \\
\text { (znaczenie polskie) }\end{array}$} & \multicolumn{1}{|c|}{$\begin{array}{c}\text { Znaczenie rosyjskie } \\
\text { /ukraińskie }\end{array}$} \\
\hline 1 & dejaki wykłady & w zn.: niektóre & ros. некоторыe, ukr. деякі \\
\hline 2 & tworzec & w zn.: twórca & ros. творец, ukr. творець \\
\hline 3 & gigijena miejsca pracy & w zn.: higiena & ros. гигиена, ukr. гігієна \\
\hline 4 & gastrole & w zn.: występy & ros. гастроли, ukr. гастролі \\
\hline 5 & repetycje & w zn.: próby & $\begin{array}{l}\text { ros. репетиции, } \\
\text { ukr. репетиції }\end{array}$ \\
\hline
\end{tabular}


Tabela 3 (cd.)

\begin{tabular}{|c|c|c|c|}
\hline Lp. & Przykład & $\begin{array}{c}\text { Powinno być } \\
\text { (znaczenie polskie) }\end{array}$ & $\begin{array}{l}\text { Znaczenie rosyjskie } \\
\text { /ukraińskie }\end{array}$ \\
\hline 6 & tak jak wyjechała & w zn.: ponieważ & ros. так как, ukr. так як \\
\hline 7 & postupiłem na uniwersytet & w zn.: dostać się & $\begin{array}{l}\text { ros. поступить, } \\
\text { ukr. поступити }\end{array}$ \\
\hline 8 & $\begin{array}{l}\text { zwycięńtswo otrzymał same } \\
\text { ja }\end{array}$ & w zn.: dokładnie & ros. именно, ukr. саме \\
\hline 9 & nie byłem zdywowany & w zn.: zdziwiony & $\begin{array}{l}\text { ros. удивлен, } \\
\text { ukr. здивований }\end{array}$ \\
\hline 10 & czarno-biała okrasa & w zn.: maść & ros. окрас, ukr. забарвлення \\
\hline 11 & porody britańskiej & w zn.: rasa & ros. порода, ukr. порода \\
\hline 12 & czarny oszyjek & w zn.: obroże & $\begin{array}{l}\text { ros. ошейник, } \\
\text { ukr. нашийник }\end{array}$ \\
\hline 13 & czytacze & w zn.: czytelnicy & ros. читатели, ukr. читачi \\
\hline 14 & detektywny serial & w zn.: kryminalny & $\begin{array}{l}\text { ros. детективный, ukr. } \\
\text { детективний }\end{array}$ \\
\hline 15 & na co zdatni głowni heroji & $\begin{array}{l}\text { w zn.: do czego są zdolni } \\
\text { główni bohaterowie }\end{array}$ & $\begin{array}{l}\text { ros. на что способны } \\
\text { главные герои, ukr. на що } \\
\text { здатні головні герої }\end{array}$ \\
\hline 16 & elektrostancia & w zn.: elektrownia & $\begin{array}{l}\text { ros. электростанция, } \\
\text { ukr. електростанція }\end{array}$ \\
\hline 17 & głównie to wierzyć w siebie & w zn.: najważniejsze & ros. главное, ukr. головне \\
\hline 18 & z ekskursią & w zn.: wycieczka & $\begin{array}{l}\text { ros. экскурсия, } \\
\text { ukr. екскурсія }\end{array}$ \\
\hline 19 & z nasolodą & w zn.: przyjemność & $\begin{array}{l}\text { ros. удовольствие, } \\
\text { ukr. насолода }\end{array}$ \\
\hline 20 & można prowietrzyć łazienkę & $\begin{array}{l}\text { w zn.: wywietrzyć } \\
\text { /przewietrzyć }\end{array}$ & $\begin{array}{l}\text { ros. проветрить, } \\
\text { ukr. провітрити }\end{array}$ \\
\hline 21 & $\begin{array}{l}\text { w komplekcie idzie dwa } \\
\text { krzesła }\end{array}$ & $\begin{array}{l}\text { W zn.: w zestawie } \\
\text { / komplecie są }\end{array}$ & $\begin{array}{l}\text { ros. в комплекте, } \\
\text { ukr. в комплекті }\end{array}$ \\
\hline 22 & ważko & w zn.: trudno & ros. тяжело, ukr. важко \\
\hline
\end{tabular}

Źródło: opracowanie własne

Część z zaprezentowanych w tabeli zapożyczeń można zrozumieć, posiłkując się skojarzeniami i kontekstem, np. kot miat czarny oszyjek, postupitem na uniwersytet czy ogladat detektywny serial. Większość jednak uniemożliwia komunikację. Czytający nie zrozumie intencji piszącego, nie domyśli się znaczenia wyrazów w wyrażeniach typu, np.: gastrole byli ciekawe, nie byłem zdywowany, robie to z nasoloda.

Osobną grupę interferencyjnych błędów leksykalnych stanowią uchybienia w zakresie frazeologii. W analizowanych pracach stanowią one jednak niewielką grupę. Przykłady tego typu błędów przedstawiono w tabeli 4. 
Tabela 4. Błędy w zakresie frazeologii

\begin{tabular}{|c|c|c|c|}
\hline Lp. & Przyklad & $\begin{array}{c}\text { Powinno być } \\
\text { (znaczenie polskie) }\end{array}$ & $\begin{array}{l}\text { Znaczenie rosyjskie } \\
\text { /ukraińskie }\end{array}$ \\
\hline 1 & $\begin{array}{l}\text { oglądałam na jednym } \\
\text { oddechu }\end{array}$ & w zn.: jednym tchem & $\begin{array}{l}\text { ros. на одном дыхании, } \\
\text { ukr. на одному подиху }\end{array}$ \\
\hline 2 & pocieszyć oko & w zn.: nacieszyć oko & $\begin{array}{l}\text { ros. порадовать глаз, } \\
\text { ukr. потішити око }\end{array}$ \\
\hline 3 & $\begin{array}{l}\text { łącząc przyjemne } \\
\text { z korzystnym }\end{array}$ & $\begin{array}{l}\text { w zn.: łączyć przyjemne } \\
\text { z pożytecznym }\end{array}$ & $\begin{array}{l}\text { ros. совмещать приятное } \\
\text { с полезным } \\
\text { ukr. поєднувати приємне } \\
3 \text { корисним }\end{array}$ \\
\hline 4 & nie urodziłem się w koszulce & $\begin{array}{l}\text { w zn.: być w czepku } \\
\text { urodzonym }\end{array}$ & $\begin{array}{l}\text { ros. родиться в рубашке, } \\
\text { ukr. народитися в сорочці }\end{array}$ \\
\hline 5 & nie spłoszyć powodzenia & w zn.: nie zapeszyć & $\begin{array}{l}\text { ros. не спугнуть удачу, } \\
\text { ukr. не сполохнути удачу }\end{array}$ \\
\hline 6 & widok odkrywa się & w zn.: widok roztacza się & $\begin{array}{l}\text { ros. открывается вид, } \\
\text { ukr. відкривається краєвид }\end{array}$ \\
\hline 7 & nastąpił czas & w zn.: przyszedł czas & $\begin{array}{l}\text { ros. настало время, } \\
\text { ukr. настав час }\end{array}$ \\
\hline 8 & otrzymuje zadowolenie & w zn.: czerpać przyjemność & $\begin{array}{l}\text { ros. получать удовольствие, } \\
\text { ukr. отримувати } \\
\text { задоволення }\end{array}$ \\
\hline
\end{tabular}

Źródło: opracowanie własne

Niewielką liczbę błędów frazeologicznych można uzasadnić tym, iż na niższych poziomach zaawansowania językowego znajomość frazeologizmów nie jest wymagana. Są one stopniowo i w ograniczonym zakresie wprowadzane do materiału językowego. Z kolei osoby o wyższej kompetencji językowej mogą stosować strategię uniku: nie używają frazeologizmów w obawie przed popełnieniem błędu.

Podsumowując, zaprezentowane w tabelach przykłady pokazują, w jaki sposób błędy leksykalne rzutują na jakość wypowiedzi pisemnych zdających egzamin certyfikatowy na poziomie B1, na zrozumienie ich intencji, a więc skuteczność komunikacyjną. Liczba i charakter tych błędów przekłada się bezpośrednio na ocenę z modułu Pisanie, gdyż jednym z kryteriów oceny jest komponent leksyka i frazeologia. Zaburzenia słownikowe, powodujące niezrozumienie wypowiedzi, mogą więc wpływać w znaczący sposób na ostateczną ocenę z egzaminu.

$\mathrm{Z}$ ankiet, wypełnianych przez zdających oraz z rozmów z nimi, wynika, że zdecydowana większość (ok. 80\%) piszących egzamin na poziomie B1 uczyła się języka polskiego samodzielnie podczas pobytu w Polsce - najczęściej podczas towarzyskich i zawodowych kontaktów z Polakami. Silna początkowo motywacja z czasem słabnie, ponieważ dzięki podobieństwu języków uczący się są skuteczni komunikacyjnie mimo popełnianych błędów. Z tego względu 
wpadają często w tzw. „pułapkę komunikatywności” (zob.: Skalska, Skalski 1995, s. 49-57), wychodząc z założenia, że interlokutor i tak zrozumie sens przekazu.

Zupełnie inaczej pod względem poprawności językowej wyglądają wypowiedzi (pisemne i ustne) osób, które deklarują, że uczyły się języka polskiego na kursach językowych. Jest to uzasadnione, gdyż w tym przypadku nauka odbywa się w oparciu o katalogi tematyczne opracowane przez autorów Programów nauczania języka polskiego jako obcego. Poziomy A1-C2 (Janowska i in. 2011 Programy) oraz przygotowywane w oparciu o nie podręczniki wiodące i materiały uzupełniające. Lektorzy i autorzy materiałów dydaktycznych mogą się też posiłkować różnorodnymi słownikami przydatnymi w nauce JPJO. Należą do nich, np., Podstawowy stownik języka polskiego z zarysem gramatyki polskiej opracowany przez H. Zgółkową (Zgółkowa 2008) czy publikacja Z. Cygal-Krupy Słownictwo tematyczne języka polskiego. Listy frekwencyjne i rangowe (Cygal-Krupa 1986). Glottodydaktycy mają również do dyspozycji pionierską publikację A. Seretny poświęconą kompetencji leksykalnej uczących się JPJO (Seretny 2011), w której, oprócz części teoretycznej, znajduje się także część empiryczna, przydatna do opracowywania ćwiczeń leksykalnych.

Lektorzy JPJO przygotowują również własne, autorskie zadania dopasowane do omawianych zagadnień i tekstów, których celem jest rozwijanie kompetencji komunikacyjnej poprzez poszerzanie zasobu leksykalnego. Zdają sobie bowiem sprawę z tego, że bez ,[...] konsekwentnego prowadzenia stałej, regularnej pracy nad wzbogacaniem słownictwa uczniów [...], nie będzie możliwy dalszy rozwój sprawności mówienia, słuchania ze zrozumieniem, czytania, pisania" (Komorowska 2001, s. 15).

Osoby legitymujące się wschodniosłowiańskim pochodzeniem stanowią obecnie najliczniejszą grupę uczących się JPJO i zdających egzaminy certyfikatowe, dlatego użyteczne byłyby również opracowania poświęcone nauczaniu leksyki w ujęciu konfrontatywnym. Jednak do korzystania z nich potrzebna jest dobra znajomość języków wschodniosłowiańskich. Mając świadomość faktu, iż interferencyjne błędy słownikowe mogą nie tylko powodować poważne zakłócenia komunikacyjne, ale często także ośmieszać nadawcę, należy przygotowywać jak najwięcej ćwiczeń utrwalających i automatyzujących użycie słownictwa, dopasowanych do tematu zajęć i poziomu nauczania JPJO, aby minimalizować liczbę błędów leksykalnych zarówno w pisemnych, jak i w ustnych wypowiedziach uczniów. Podobieństwo języków przyspiesza niewątpliwie nauczanie polszczyzny w grupach wschodniosłowiańskich, ale $-\mathrm{z}$ drugiej strony - może jednak je utrudnić, gdyż w zakresie leksyki czasami bywa tylko pozorne. 


\section{BIBLIOGRAFIA}

Cygal-Krupa Z., 1986, Stownictwo tematyczne języka polskiego. Listy frekwencyjne i rangowe, Kraków.

Czapla A., 2020, Blędy leksykalne Ukraińców uczących się języka polskiego w Polsce, „Linguodidactica", t. XXIV, s. 29-44, https://doi.org/10.15290/lingdid.2020.24.03

Czernysz T., 2005, Polsko-ukraińskie pułapki językowe: korzyści i trudności nauczania języka polskiego w kontekście bliskości lingwogenetycznej i typologicznej, w: P. Garncarek (red.), Nauczanie języka polskiego jako obcego i polskiej kultury w nowej rzeczywistości europejskiej, Warszawa, s. 477-481.

Dąbrowska A., Pasieka M., 2008, Nowa typologia błędów popetnianych przez cudzoziemców w języku polskim, w: M. Kita przy współudziale Czempki-Wiewióry i M. Ślawskiej (red.), Błąd językowy w perspektywie komunikacyjnej, Katowice, s. 73-102.

Dunin-Dudkowska A., Maliszewski B., 2018, Jak lepiej (nie) pisać? O błędach popetnianych przez Ukrainców zdajacych egzamin certyfikatowy z języka polskiego jako obcego, w: A. Krawczuk, I. Bundza (red.), Polonistyka w XXI wieku: między lokalnym a globalnym, Lwów, s. 354-363.

Dziennik Ustaw, 2012, poz. 161, roz. IV, art. 30, p. 7.

Europejski system opisu kształcenia językowego, 2003, Warszawa.

Górecki M, Stawska M., 1993, Błędy językowe charakterystyczne dla młodzieży polskiej ze Wschodu, w: J. Mazur (red.), Metody kształcenia językowego Polaków ze Wschodu, Lublin, s. 49-55.

Izdebska-Długosz D., 2016, „, Czyje są te syny?”, czyli o błędach w rodzaju męskoosobowym popetnianych przez studentów ukraińskojęzycznych, w: A. Roter-Bourkane, A. Kwiatkowska (red.), Horyzonty nauczania języka polskiego jako obcego, Poznań, s. 43-57.

Janowska i in. (red.), 2011, Programy nauczania języka polskiego jako obcego. Poziomy A1-C2, Kraków.

Komorowska H., 2005, Metodyka nauczania języków obcych, Warszawa.

Kowalewski J., 2015, Czy można się uczyć na błędach? Wnioski dydaktyczne wynikające z analizy błędów popetnianych przez uczacych się języka polskiego na Ukrainie, w: I. Bundza, J. Kowalewski, A. Krawczuk (red.), Język polski i polonistyka w Europie Wschodniej: przeszłość i wspótczesność, Kijów, s. 361-376.

Krawczuk A., 2006, Błędy gramatyczne studentów polonistyki lwowskiej spowodowane polsko-ukraińska interferencja, „Postscriptum”, nr 2 (52), s. 137-153.

Maliszewski B., 2014, Per errata ad astra - zwalczanie interferencji gramatycznych $w$ procesie nauczania języka polskiego studentów ze Wschodu, w: M. Dziwisz i in. (red.), Błąd w literaturze, kulturze i językach narodów stowiańskich, Lublin, s. 221-230.

Przechodzka G., 1993, Z problematyki interferencji językowej w nauczaniu języka polskiego Polaków ze Wschodu, w: J. Mazur (red.), Metody ksztatcenia językowego Polaków ze Wschodu, Lublin, s. 39-48.

Seretny A., 2011, Kompetencja leksykalna uczących się języka polskiego w świetle badań ilościowych, Kraków.

Stownik języka polskiego PWN, 1981, M. Szymczak (red.), Warszawa.

Szulc A., 1984, Podręczny stownik językoznawstwa stosowanego, Warszawa.

Żydek-Bednarczuk U., 1993, Błędy językowe a zjawisko interferencji międzyjęzykowej, „Przegląd Glottodydaktyczny", t. 12, s. 69-82. 
Grażyna Przechodzka, Wiktorija Hudy

\section{LEXICAL INTERFERENCES IN WRITTEN TEXTS OF SLAVS FROM THE EAST (BASED ON WRITTEN CERTIFICATE PAPERS OF 2019, LEVEL B1)}

Keywords: interference, lexical errors, negative language transfer, certificate exam, level B1

Summary. The article presents an analysis of lexical interference errors made by Slavs from the East. The authors made an attempt to classify them and indicate the source of their occurrence. The source material consists of written texts, selected from certificate tests (level B1). The errors were divided into several groups due to their impact on the communicative effectiveness of people of East Slavic origin learning Polish as a foreign language. The presented material can be used as a base for development of didactic tasks preventing lexical interference. 
